Int roduct ion

in designing the PEP optical diagnostics ve have been able to bulld on the experience gained with SPEAR. ${ }^{1}$ Mast of the problems at SPEAR could be craced to the opt Lcal diagnost $j c$ systen being fnside the tunnel. nel. A machine shutdown is required for any maintenence or modification. This implies that in order to nake guch on ingtrument successful, a large engineering iffort must be rounted to ensure $100 z$ operation at startup. The functions that do not work at startup pay never be eade to work: this has happened at several pachines. Experimental setups are likeulse risky and tine consulag.

A polnt which las been borne out is buch SPEAR and PEF is that the mectanical part of the 1nstrubent, the special vacuum chamber, the optical mounts, the alignment and adjugtments, require approximately 602 of the effort and cost of the optical diagnostics. It is far better tu econsizize on detectors and electronics than on mechanted and optical essentials.

\section{Jacuum Chaber:}

The two PEP primary mirrors, one each for $e^{t}$ and $e^{-}$, are of pure Be, flat and opt Ically polished. clamped to voter-cooled nounts on the chaber wall. The mirrors share one chamber at one are symetry point. A slot $5 \mathrm{~mm}$ high suts through both at the bean median plane to allow the powerful smal! angle $x-r a y$ flux to pass through without heating the mir:ors, for good closed orbles. The design of the nirrors is thus ingervative: Be firtors can withstand the radiat on frot a naxicat: beap ut thout pemanent deformat $1 \mathrm{n}$, l but under 1 ormat aperating canditions they see very little therwal load. Aligiment of mitrer: is done $1 \mathrm{n}$ the vacuut baburatorw ouring final isembly. Since the (Be) wirrors art closely (optica:ly) fcllowed by adjustable mirrors, the alignment tolerance $1510^{-2}$ radian on two axes. The mirrors have no adjustments outside the chamber.

The exi: ports are symethetic fused quartz discs, 13 gor thick, is en diaseler, sealed to flanges through glass gr=des. Systes aperture at this point is decermined by the Be itirrots, vhose elifptical surface defines a 6.4 cit dlameter clatle. The excess diarecer of tne ports a:lows for eptical distoriton at the edges due In the segling process. To improve the RF impedance of the chamiber, a fint BeCu screen shlelds the exit port.

Wibration is a serlous concern in this gystem since the source, the bean, is 6 th from the first uptical element. the Be mifror. A tolerance of $50 \mathrm{um}$ for vibrationinduied image degradar fon gives an angular vibrazton inte of $10^{-t}$ ractan. Dexalled studtes ${ }^{2}$ shoued the malor Durce of vibration to be the ritror water rooling. The chather design is heavy and solid to minimize vibrasion: $500 \mathrm{Kg}$ of sand in the chapber support stand also serves as a daming nass.

Tro chambers on each side of the mirrol chamber need special deston to alios horiznntal $\left[7 \times 10^{-3}\right.$, añ vertical ( $) \times 10^{-3}$ ) aperture for the visible synchrotron light. This is in concrast uith SPEAR in which only mirror chambers were required. The difference lles in the rat 10 of beas stay-clesr diameters to magnet bend 1 ng radif in the two rings.

\footnotetext{
- hork supported by the Department of Energy, contract DE-ACO3-765FODS1S.

+ Dynasil 1000. This materjal has excellent tesistance co radjat Ion darkening.
}

\section{Opt 1Cs:}

The verrical opening angle for visible (600 ral ) synchroricon light is $2.4 \times 1 \mathrm{O}^{-3}$ radian FWh in PEP at all energles. The ultimate resolucton lintt (Table 1 ,

Table 1. Parameters Lisc, E - 15 GeV

\begin{tabular}{|c|c|}
\hline $\begin{array}{l}\text { Vertical opening angle } \\
\text { of Ifght, } h-600 \text { mo } \\
\text { Instrument angular aperture } \\
\text { Vistble } 11 \text { ght power } 400 \text { ma } \\
\text { to } 800 \text { men }\end{array}$ & $\begin{array}{l}2.4 \times 10^{-3} \text { radian Fhrly } \\
3 \times 10^{-3} \text { radlan vert } 1 \text { cal } \\
7 \times 10^{-3} \text { radian hor } 120 n t a l \\
5.3 \times 10^{-6} \text { wat } \text { s } / \text { ma (beam) } \\
\text { m radian (hot } 1 \text { zont al angle) }\end{array}$ \\
\hline $\begin{array}{l}\text { Vertical resolution limit. } \\
\text { diffeaction limited, at } \\
600 \text { nafull udth baximun }\end{array}$ & 220 pm \\
\hline $\begin{array}{l}\text { Angle brtween line of glght } \\
\text { s line ot emission points }\end{array}$ & $\arctan 21.5$ \\
\hline $\begin{array}{l}\text { Distance frod beam point } \\
\text { to first (Be) etrror }\end{array}$ & $6.17=$ \\
\hline $\begin{array}{l}\text { Lattlce function values at } \\
\text { opt leal aonitor }\end{array}$ & $\begin{array}{l}B_{x}=19.2 \mathrm{~m} \\
B_{y}=17.70 \mathrm{~m} \\
3 x=1.13 \mathrm{~m}\end{array}$ \\
\hline Bending radius at bean poinc & $165.5 \mathrm{~m}$ \\
\hline
\end{tabular}

of a vistble ligh orticei wontcor to set by this opening angle. The resolution is degraded by geometric effects ${ }^{3}$ lavolving the hear sire, the horlzontal aperture of the inseruent and orbit ghifes.

The ultimate resolution at 600 no $1 \mathrm{~s} 220 \mathrm{um}$ FMps.

The horizontal beam size ( $5 \mathrm{~m}$ ) increases this co 230 um and using the full horizontal aperturc of the instrument $\left(7 \times 10^{-3}\right.$ radian) increases it to 600 wo. Orbit shifts not gredter than $: 3$ de not requite focus correction, althugh ch1s capability exists in the instruent. The horizontal fleld cust be stopped down to $.5 * 10^{-3}$ radian to ut 11 ize the full resolution of the system.

The criterion that all the opt lcal elewents possible $a_{i}$ to be accessible dur Ing bean operation puts the first focussing element 23 m $\mathrm{f}$ or the lighe oource. To achleve an overall magnification $>1$ in a liniced opace, we use a Newtonian reflecting telescope with an "eyeplece" magnifler (Fig. I). The spectfied field of ulew of the releacope is 40 dienee:s circle at $20 \mathrm{an}$, an angular fleld of $2=10^{-3}$ radian, but the fleld within wich high resolution is needed 191 \% $10^{-6}$ radian This is vell vithin the "good" field of a spherical raflect or." even then the prite lage is agnifled. Caleful cullteation of the spherica! reflectors 15 . of sourse, requited.

At the botcon of the $10 \mathrm{~m}$ long $61 \mathrm{cD}$ dlameter verical shaft lead'ng up to thi opt ics buidding. 1.5 m $f$ rom the exit port on the vacuum chamber, $1 \mathrm{~s}$ a $15 \mathrm{~cm}$ dianeter circular plane mirror on a 2-axis, remoce. controlled, angular-vartable mount. This adjusement brings the syishrotron light stralgl.t up the long thaft and constitutes the priae aligreent of the gystem.

At the tep of the shaft a plane witror brings te light into a horizonial (normal to gravity) plane, and

SOne system cnly is discussed. All of the description appl: 's to bath except where noted. 


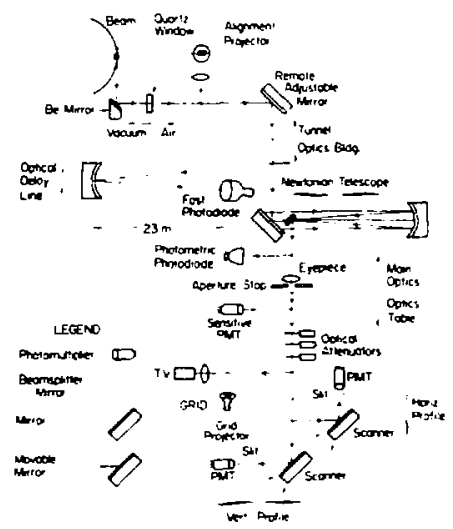

F18. 1. Schematle of one side, $e^{-}$, of optical ronitors. Bunch length measuratent exists only on the $e^{-}$side.

Into the Nertonian telescope. The der Lal, M- 1, Lage is formed in the sace plane over the surface of a 1.5 . 2. I I laboratory optical table. Al the optical conponenta comprising the detector system are bolted to the table's flat aurface in the style of optical research get-ups.

An aperture stop 15 used in che horlzontal nlane only. Tro fndependent ly adjustable blades define the horfiontal aperture at the eyepiece lenk of the celescope.

The optics bullding is $10 \times 10 \mathrm{~m}$. and contalis the telescopes, detector electronics, the optical table. work and storage spoce. The optical syetem fron the vacurr chamber to the telescope cyeplece is sealed and alrtight. The optical cable has a dugtproof lighttight enciosure.

\section{Detectors}

\section{Injection Phococulctplier}

A 14-stage photosultipler sees the ent lre field of view of the celescope chrough a :07 pellicle beamsplitcer. The dircet signals, rtretched electronically and viewed ditectly on an oscillofcope, are very useful during firat injection into a newly bet-up ring.

\section{Phosometris Bear Current Meawuresent'}

The 1 ight fros tre whole : 1eld, via a $10 \mathrm{z}$ beaneplitter, Is broughe onto the surface of a $25 \mathrm{mdiame-}$ ter $\$ 1$ phocodiode, operaced in the photovoltalc wode to el ininate dark current. The current is amplifled, f1]teied and read by digital voltoeter into the CaraC bystem. A CAHAC-controlled ahutter in front of the slode is used to eet zero. A Cat display ghouing current a a function of cime, 1 llectpe and $f 111$ race 18 a primary diagnostic.

\section{Bunch-by-Bunch Photomecr lc Heasurement}

As above, but a fast, blased $S 1$ photodfode 15 uacd followed by fast ampIIflere and single-pang A/O conversion. This allows measurement of the currert in the three separate bufiches per bear.

* By Newport Regearch Corporat lon,

+ Thir plagtic filo strecched over a lapped frase.'

\section{Teleyibion}

A 102 begnsolitcer leads to an arrangenent of Lenses, grid profector and TV camera which produces a head-cin Image of the beam mixed with a dimension gidd (Fig. 1) The camera uged is 3 ccumercial vidicon cupe. At cenuat ing filtera controlled from the machtnc coniole in at 1.3, 10 sequence are upstreas of the TV carera. The center of the dimension Brid is used operaticnally as the reference center for the bear in the entire instruent.

\section{Quant itative Profile Meagurement}

The atored beams have tro-fold symetry abouk perpendicular axes. Tro slit or Itne scans compleculy define the bean density distibucinn. Out ef a varicty of scanning aethods rossible. the PEP ponitors use aechanical acanning of the imges acrose sitis folloued by photorult iplier latenuity detectors.

The blits and photosultipliters are stat: onary.

the Inagea belag asgle-acanned by servo-cortected electrowechanteal scanners," The suep vidth, tate and center position can be adjusted, since che scanners have a IInear response In angle of. T radian full uidth with a frequency response atarting at $D C$ and rolling of above $100 \mathrm{~Hz}$. The scanners can be stopped so that a chosen postcton on the hear image is fixed over the olit, and the photodetector signal studfed va an osc111oscope, spectrum anaiyzer, etc

PEF's three bunches per beam are separated th 2.5 we, the time resolution of the scannet PMT's is 2 ns. The pulse train coning out of a scannet ictertor contalns three c ine aultiplexed prof!les, uhic!; are demultiplexed and gtretched with pated sample-anithold circults. Elther one of the three sunch srof $\vdots$. a is selec ad and displaved, or all three art sumet it display.

To avold detector saturation, atrenual ing filters are put upatrean of the scanner devices. These Jr" tho saser fllters which level the light for the : $x:{ }^{\prime}$ vision ceneras. The vertical protile slit an bt tlted ir. angle under recote concrol to sapencate fivr beas $t 13 t$.

\section{Bunch Length Measureent}

The symchrotron $11 \mathrm{ght}$ is modulated with the elt tron bunch lengch Inforwacton," The fast phetodlodt used is the sume one used at SPEAR. 5 a fator trotint cal problew is the stable triggering of the sargiting osc11!oscope which Iraks at the photodiode signal. A: PETRA $^{7}$ chis has teen solved with a preclst eltctronts countdoun of the ring radio frequency.

Although a signal dertved frae a plekup electrace provides a very acable trigger, approxfaucelv solncldent with the first artival of the synchrotron lifit pulse, $\delta$ sempiling oscilloscope requires a $=100 \mathrm{~ns}$ prex 1gger. We delay the Ifght pulse by daflec:ing 10 into a 23 of in length section of $60 \mathrm{ct}$ steel pipe burled in the earth adjacent to the opt fics bulldinf, reflecting it back into the photodetector. A rercte controlled opclial delay of 300 ps can he insortes for t tne callbrat ton.

The crigger is put in colnctdence with gachino criggers ta aelect one of three bunches. The buni?. stgnal Is stable and reproducibje.

\section{Test, Alggnent and Callbration}

The be mirror and the quartz uindows were tested by etandard optical methods. The uindous, wich azut less than $\lambda / 4$ distortion before being fused int $c$ the class grades. were distorted as ouch as $2 \mathrm{~h}$ tn thrwrat case.

The optical systed was tested in situ in the rink. The mirtor vacuos chapber was installed and alignid wich charbers removed through the first adjacent bend

I Hanufactured by General Scanning Corporacion. 
nagnet. Temporary windoug on the ends of the yacuur chamber kept it elean through the opt cal tests. Uging sources and targets posicioned at the emission point in the bend magnets, the plane reflecting mitrors and focusaing clements were aligned. The system magnification and reaolution were defined with white and filtered white light. The results showed system resolut ion much saller than the synchrotron light diffraction 1 im $1 \mathrm{t}$.

\section{Startup, Operation and Mod 1f Lcations}

In the first daye of PEP operation, the full aperture photomulcipliers provided one of the chief clues to the progress of bear storage. They have served the function of f1rst-used machine dlagnostic Blace and their function is so necescary that ve inrend to move thom Into the tunnel, where they will be unaffected by any posalble misaligment problem.

As soon as bese was stored, the television caseras case into use. The effective field of vieu on scresen, based on predicted orbit correctiong, was $15 \mathrm{~mm} \times 15 \mathrm{~mm}$. From day-to-day, the beam spot was completely of $\frac{1}{2}$ the TV camera. We finally realized that th1s vas due to very large local orb $\pm t$ discorelons, and remoce control alfgrment of the systen to keep the trage centered has been added.

Beat current measurement 15 essent 101 in studying injection rates and beam iffetime. The photometric system exhibited extrerje sensifivity to orblt changes. this being trared to 1 ts position on the optlcal table dounstreas of numerous apertures. A move upatrean to a point uthin the telescape near the prine focus has greatly improved the stabli1ty of current measureaent. espectallv for the caie of copping up a stored besm, a situation in which the photomultififer is not usable. The short lern stability of current measurement has reached $l \times: 0^{-3}$ with a $\left.f 1\right\}$ tering $t$ inc constant of $1 \mathrm{~s}$.

then the optical system is out of focus, two beam inages appear. This is due to the slot in the primary (Be) mitror. This effect is useful for focussing the lmage in the same manner ai a split-image range finder on a camera. If the celescope is seriously miscolitarted, the two images can appear quite different, even having different tilts. The slot passes enough visible synchrotron light power to cause errors in the photometric bean-current geasurement system due to verteal orbit shifts.

Th2 smallest vertical prof 1 ? 750 wa miss, auch 3 arger than the theoretical Eininan of 230 ur. Systematic work remains to be done to separate the contributiors co the measured profile size from optical and beam effects.

The long lever arms and the large number of adjustable components make the aligntrent of the systero crit1cal and easy to upset. An internal alignent syster has been added which projects the leage of a reticle chrough the whole syscen. for both $\mathrm{e}^{+}$and $\mathrm{e}^{-}$. Into all detectors. This lets us adjust and podify the systes durlng beas-off times vithout having to fear a migaligned instrument at startup.

The alt column in the $10 \rightarrow$ vertical shaft connecting the cunnel with the opclcs bullding can be unscable, al though thete $1 \mathrm{~s}$ no through motion of $\mathrm{air}$. The image of the beam has beell obstrved to bcintillate as much as 100 un af ter the alr seal has been broken and the air in the shate is not in equilibrium. Th1s is generally not a sertous prubleto, but correct fve measures arr under study, including a slov, laminar motion of air through the shaft.

\section{C ntrol and Interface}

Host c-ltical functions, e.g., at tenuat lng filers, scanned bean profile, are hard-vired to PEP control, approx 1000tely 200 in 5 rom the optics bullding. Photometric Leam current rearlings are caken at the bullding. feeding ca a CAMAC branch connected to the PEP central computer. ${ }^{\circ}$
The irofile scanners, controlled by an input voltage, are computer-driven via a CAHAC D/h channel. The voltage levels corresponding to $11 \mathrm{ght}$ intensity on the profile are similarly read back to the computer. The selection of separate bunches can be computer-controlled. as can vartous shuters to set baselines. CenterIng the beams on the scan is cimple, ance a beam centered on the television camera crosshatrs is centered on the acan.

The aupling osetlloscope uoed for bunch length measuremest is in the optlcs bullding, physically cloge to the fast phocodiode. The lou-frequency horizontal and vertical output signals frow the obc1l loscope are sent over analog channela to PEP control for routine display.

\section{Conclusions}

Euldding the diagnostic system out of the curmel has been worth the effort. Madificationg have been made on almost all systens, and a completely neu gystem, the bunch-by-bunch current measurement, has been developed during physics runing un PEP. Hew detectors, CCD-Bcanned photodlode arraya, have been lested and inatalled by others on the optical table, and machine physics expertmenters have usad the optics bullding as a laboracory.

The ultimate vertical resolucton of the instrument Is just at the limit of being ugeful for overell agchine coufi:th studies. For higher resolution on a wachlne of the same size, one tust use ultraviolet optics or $x$-ray devices" such as the one now installed on PEP. For machines vith larger radil of curvature. such gystems are absolut 1 ly necessary.

\section{Acknoulengment s}

The vacutro chamber was engineercd and designed by B. Scott and C. Parking, respectively. The electronics we:t engineeryd by R. Partelou anu brought into opera$t$ ion by $W$. Roster. Espectally foportant have been the contributious of $v$. Lee in the design and execution of sost of che opclcal and gechanical prectaion devices in the system.

\section{Ref erences}

1. A. P. Sabersky, Monitoring the Beags in SPEAR with Synchrotron Light, IEEE Trans, on Nucl. Sc1. H:S-20 (1973), Pp. 638-4i.

2. v. Cumings, ed, "The Vacuum Systew for PEP," SLAC -231 (to be published).

3. h. P. Sabersky, "The Geonetry and Optics of Synchrotron Light," Particle Accelerators S. No. 4 (1973), Pp. 199-206.

4. M. Born and E. Holf, Principles of Optics, 2nd edition, Macmilian (1964), pp. 245 .

5. I. H. Hunro and A. P. Saberaky In Synchrotron Radiation Acsearch, eds. HInlck and Donlach, Plenure (1980) PP. 328-9.

6. P. B. Wlison et al . Bunch Lengthening In SPEAR I1, IEEE Trans. Nuel. Sc1, t5-24 (1977), Pp. 1211-1214 S. PHc zold, "Bunch-Tr1gger-Generaccren fuir DORIS und PETRA." DESY HZ- T7/02 (\$97T).

8. R. Melen, "The PEP instrumentat 1on and Control System," 1lth International Conf. on High Energy Accelerators, Experient1a Supplementum, V. 40, Elrkhbuger Verlag (1980). pp. 408-20.

9. R. St Lening and $K$. Jobe, private cutarinlcation. 